\title{
THE SUGGESTION OF LIMITED CORPORATE GOVERNANCE STANDARDS IN NIGERIA AND SOUTH AFRICA-IMPLICATIONS FOR MANAGEMENT AND GOVERNANCE IN DEVELOPING COUNTRIES
}

\author{
PHAM VAN TUAN ${ }^{1} \&$ DINH TRAN NGOC HUY ${ }^{2}$ \\ ${ }^{1}$ Research Scholar, National Economics University, Hanoi Vietnam, Vietnam \\ ${ }^{2}$ Research Scholar, Banking University of Ho Chi Minh City, International University of Japan, Japan
} \begin{abstract}
The role of corporate governance including IT governance is aligned with corporate governance and It governance, together with IT security policy, will help to enhance the strength of corporate governance. And this is a crucial part of firm corporate governance structure. Corporate governance is defined as the entire structure, process, and law under which a business controls and operates.

Good corporate governance will contribute improve the efficiency and transparency of the stock market, with important implications. Hence, this paper will set a standard set for corporate governance in selected African countries including Ghana and South Africa, whereas it takes advantage of CFA and ACCA CG code as references. Then it will suggest implications for developing countries application such as Vietnam, etc.

KEYWORDS: IT security and Governance, Corporate Governance Standards, South Africa \& Nigeria
\end{abstract}

Received: Jun 06, 2020; Accepted: Jun 26, 2020; Published: Jun 30, 2020; Paper Id.: IJMPERDJUN2020147

\section{INTRODUCTION}

There Are Many Good Aspects of Corporate Governance (CG) Consisting of:

Ensuring the long-term sustainable development of the company, because The best interests of shareholders and related parties other

- $\quad$ Creating market trust and business ethics

- Contribute to improving the competitiveness and reputation of companies, creating favorable conditions for market access capital

- $\quad$ Supporting financial market development and promoting growth economy.

This paper, hence, will present results or findings and result of comparison good CG codes in selected African countries.

\section{BODY OF MANUSCRIPT}

\subsection{Research Literature Review}

Corporate Governance is one of the hot topics that researchers are interested in. A series of events that have taken place over the years has led academic researchers, consulting firms, and the banking and financial system to put a great deal of effort into understanding aspects of this topic. Studies show that weak corporate governance is one of the reasons for scandals in the United States and the economic crisis in Asia, especially the problems with 
equalization and economic development in countries with transition economies.

Ahamed (2018) indicated that corporate performance will be better if there is an efficient working capital management (proxied by Cash conversion cycle and components thereof), then we adjust for various industry.

Gouiaa (2019) mentioned in the context that Canada with a law passed in 2003 to enhance CG, that CG mian goal is ensuring roles of board of executives who manage financial section effectively to meet best interests of stakeholders.

Then, Sabat and Krish (2020) found out that CG activities mediate the relationship between socially responsible supply chain management (SRSCM) and ER whereas it has a negligible mediation effect on the association between GSCM and ER (economic returns).

Next, Al Fadli (2020) stated that reporting CR is highly positively affected by audit committee and board size, which helps to enhance best practices of CG, with compliance.

Last but not least, Shikarwar and Sharma (2020) found out there is less correlation between stable finance and governance regulated for countries in their study. Their results emphasize that regulation need to be stronger.

Finally, corporate governance is becoming vital in recent years under economic recession, esp. under compounding impacts from China-US commerce war.

\subsection{Theory of Corporate Governance and Financial Crisis}

The company has a good corporate governance system which is very important, bringing many advantages as follows:

Promote operations and improve business efficiency

Corporate governance will provide a better accountability system, reducing the risks associated with frauds or transactions for the benefit of managers.

A high sense of responsibility combined with effective risk management and internal control can help the company to identify problems early before they arise and lead to a crisis.

Corporate governance will help improve the efficiency of management and supervision of executives. The application of effective corporate governance practices will also contribute to improved decision making.

\section{RESEARCH METHODOLOGY}

Based on $1^{\text {st }}$ group of good CG codes such as South Africa 2009 King Code and Ghana CG Principles, we make comparison and with references such as ICGN and OECD CG codes, we can propose selected African CG principles and standards which can be used to compare to other developing nations CG codes, for a better corporate governance in stock markets.

\subsection{Empirical Findings}

- Findings on Corporate governance issues after financial crisis, corporate scandals and market manipulation

It is necessary to clearly distinguish the concept of corporate governance and Business Management. Business administration is the administration and management of production and business activities of enterprises, which is performed by the Board of Directors. Corporate governance is the process of managing shareholders' activities for the 
entire company to ensure their rights and the society. More broadly, CG develops to the interests of stakeholders who are not only shareholders but also employees, customers, suppliers, the environment and government agencies.

\section{- Findings on Manipulation in Corporate Scandals}

In 2014-2015, Volkswagen Group, the world's largest car maker, admitted to using fraudulent software on fuel consumption on about 11 of its diesel cars in the US from 2009-2015.

Beside, by the beginning of the 21 st century, when US telecommunications began to cool down, WorldCom fell into debt after the acquisitions. CEO Bernard Ebbers has used open methods to cheat accounting, conceal weak financial conditions, and forge growth to raise stock prices. In 2005, the company declared bankruptcy after the New York court confirmed that Mr. Ebbers had fraudulently recorded up to \$ 11 billion and was sentenced to 25 years in prison. This was the largest bankruptcy case in the US until that time.

- Findings on Building Comparative International Corporate Governance Standards

- Group 1: South Africa Corporate Governance standards analysis

This is the Model We Use to Build Better CG Codes for African Countries:

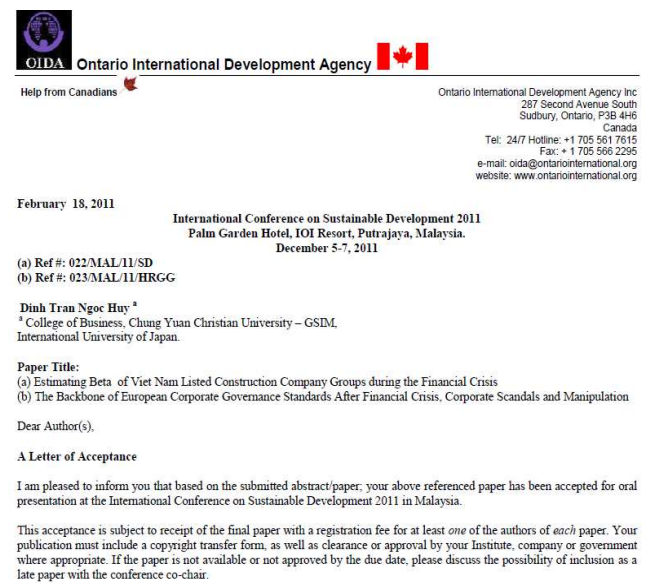

Figure 1

We Will Summarize Quality Standards of South Africa Code as Follows:

Table 1: The King Code of Governance 2009 for South Africa

\begin{tabular}{|l|c|c|}
\hline & Main Quality Standards & Sub Quality Standards \\
\hline Audit Committee & Meet >=2 times a year & Make reports to BD; \\
\hline The chair & Formalize his / her roles; & Assess performance every year; \\
\hline CFO & N / A & Not clear; \\
\hline Supervisors & May be outsiders and external experts; & Not clear \\
\hline Transparency / Disclosure & Disclose risks in reports integrated; & Not clear \\
\hline
\end{tabular}

We will summarize quality standards of Ghana CG Code as follows:

Table 2: The Ghana Corporate Governance Principles

\begin{tabular}{|l|c|c|}
\hline & Main Quality Standards & Sub Quality Standards \\
\hline Audit Committee & With limits of authority; & Invite IA head, EA to meetings; \\
\hline The chair & $\begin{array}{c}\text { Make sure quality of data /information } \\
\text { allocated to BD; }\end{array}$ & $\begin{array}{c}\text { Make sure BD contribute with } \\
\text { best capabilities; }\end{array}$ \\
\hline Board & Consist 8-16 individuals; & Take care of RM system; \\
\hline
\end{tabular}




\begin{tabular}{|l|c|c|}
\hline Supervisors & May be NEDs to supervise the chair; & Not clear; \\
\hline Transparency / Disclosure & Disclose board appointing process; & Not clear; \\
\hline
\end{tabular}

Table 3: Comparison between the South Africa and Ghana Corporate Governance Principles

\begin{tabular}{|l|c|c|}
\hline \multicolumn{2}{|c|}{ Ghana Code } & South Africa Code \\
\hline BD roles & & $\begin{array}{c}\text { Clear descriptions of roles and between group and holding co. } \\
\text { Suggestion: more description for clear picture }\end{array}$ \\
\hline Risk & $\begin{array}{c}\text { Mention risk committee in charge of process of risk } \\
\text { management }\end{array}$ \\
\hline $\begin{array}{l}\text { The } \\
\text { company }\end{array}$ & $\begin{array}{c}\text { Mention firm considered as a whole, for } \\
\text { shareholder values increasing }\end{array}$ & \\
\hline Chairman & Better description on roles & \\
\hline
\end{tabular}

\section{- Group 2: Relative Good Corporate Governance Group Analysis}

\section{CFA's 2005 Corporate Governance Standards Analysis:}

CFA 2005 principles stated that roles of CEO and chairman to maximize values of shareholders. Beside, for better disclosure, it requires better transparency by describing more risks of company's strategies and disclosure of CG structure.

From the above comparisons, we can build a standard set of selected African countries CG

\section{- The $1^{\text {st }}$ Establishment of So-Called Limited Comparative Africa Corporate Governance Standards}

\section{We summarize Key Factors as Follows:}

- For Board: it is necessary to pay attention to IT governance matter in meetings

- For Chairman: need to be conflict free

- For Audit Comm.: with proper qualification and meet at least 2 times a year.

- For Secretary of Company: need to inform BD 2 days in advance of meetings

- For Company: pay attention to $3^{\text {rd }}$ parties and stakeholders

- For Internal Control: assessment of risk in a systematic and ongoing manner;

- For Leadership: giving direction on strategy of company

\section{CONCLUSIONS}

Both Ghana and South Africa Codes prove companies with better description on roles of Chair and CEO.

The important role of the Board and the Board members in the direction and corporate governance, with the responsibilities that the company's shareholders have entrusted to them

- Working framework and operating mechanism for members of the Board to undertake or dismiss members

His responsibilities are transparent and effective

- Best practices for a competent and balanced Board of Directors, focusing on issues relating to independence, organizational structure, membership structure and performance evaluation of BOD

Last but not least, both CG Codes suggest sustainability in business operation and profits. 


\section{REFERENCES}

1. Abdulsamad, A. O., Yusoff, W.F.W., \& Lasyoud, A.A. (2018). The influence of the board of directors' characteristics on firm performance: Evidence from Malaysian public listed companies. Corporate Governance and Sustainability Review, 2(1), 6-13. http://doi.org/10.22495/cgsrv2i1p1.

2. Ahamed, N. (2018). Does working capital determine firm performance? An empirical research of the emerging economy. Corporate Governance and Sustainability Review, 2(1), 14-33. http://doi.org/10.22495/cgsrv2ilp2

3. Al Fadli, A. (2020). Corporate board and CSR reporting: Before and after analysis of JCGC 2009. Corporate Governance and Sustainability Review, 4(1), 21-32. https://doi.org/10.22495/cgsrv4ilp2.

4. Gouiaa, R. (2019). Corporate governance in Canada: A review of regulation and practices. Corporate Law \& Governance Review, 1(2), 42-50. http://doi.org/10.22495/clgrv1i2p4.

5. Sabat, K. C., \& Krishnamoorthy, B. (2020). Sustainable supply chain management practices and their mediation effect on economic returns. Corporate Governance and Sustainability Review, 4(1), 8-20.http://doi.org/10.22495/cgsrv4ilp1.

6. Samarakoon, SMRK, \& Perera, KLW (2018). Short-run price performance of IPOs and corporate governance practices: Evidence from a frontier market. Corporate Governance and Sustainability Review, 2(1), 34-42. http://doi.org/10.22495/cgsrv2ilp3.

7. Sikarwar, T. S., \& Sharma, S. (2020). An operational approach to financial stability: On the beneficial role of regulatory governance. Corporate Governance and Sustainability Review, 4(1), 74-81.http://doi.org/10.22495/cgsrv4i1p7.

8. www.cbc.to.

9. www.cii.org/corp_govenance.asp.

10. www.iasplus.com.

11. Umar, MUHAMMAD SANI, and ATANDA TAIWO Mutiu. "A firm-level analysis of corporate governance and bank performance in Nigeria." International Journal of Business and General Management (IJBGM) 5.3 (2016): 720.

12. Prusty, Twinkle, and Shweta Mehrotra. "Accentuating role of board for corporate governance in Listed Indian Companies." International Journal of Business and General Management (IJBGM) 3.2 (2014): 4756.

13. Rajharia, P. O. O. N. A. M., and B. H. A. W. A. N. A. Sharma. "Legal aspects of corporate governance for it companies in India." IMPACT: International Journal of Research in Business Management (IMPACT: IJRBM) 2.11 (2014): 3542.

14. Mohan, Aswathy, and S. Chandramohan. "Impact of corporate governance on firm performance: empirical evidence from India." IMPACT: International Journal of Research in Humanities, Arts and Literature (IMPACT: IJRHAL) 6.2 (2018): 209218.

15. ALTURKI, KHALID HAMAD. "CORPORATE GOVERNANCE AND THE ROLE OF FORENSIC ACCOUNTANTS IN SAUDI ARABIA." International Journal of Accounting and Financial Management Research (IJAFMR) 7.2 (2017):1724.

16. SOLFAIMAN, MOHAMMAD, and MOHAMMED ALI NAUSE RUSSEL. "AN INVESTIGATION TO THE PERFORMANCE OF THE VOLUNTARY CODE OF CORPORATE GOVERNANCE IN BANGLADESH AND THE SCOPE FOR A MANDATORY ONE." BEST: International Journal of Management, Information Technology and Engineering (BEST: IJMITE) 3.4 (2015):2136.

17. Owusu, Kwabena. "CORPORATE GOVERNANCE AND INTERNAL AUDIT CHALLENGES IN A DECENTRALISED PUBLIC GOVERNANCE SYSTEM IN GHANA." International Journal of Business and General Management (IJBGM) 7.6 
(2018):1730.

18. KHAN, YOUSUF, ABDUL GHAFAR, and MALINI NAIR. "EARNINGS MANAGEMENT IN THE PRESENCE OF CORPORATE GOVERNANCE QUALITY: EVIDENCE FROM THE UAE (2007-2011)." International Journal of Mechanical and Production Engineering Research and Development (IJMPERD) 9, Special Issue 1 (2019):480496.

\section{Exhibit}

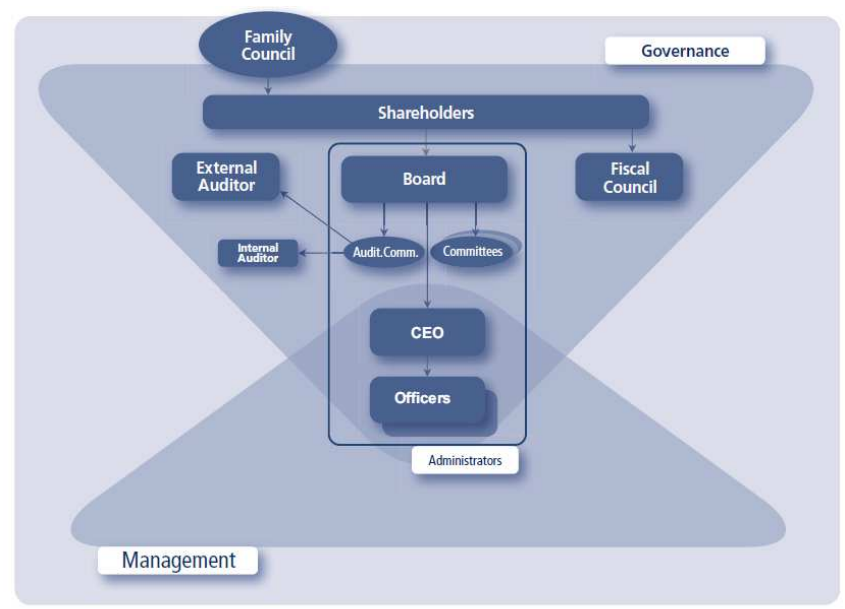

Figure 2: Brasil CG Code.

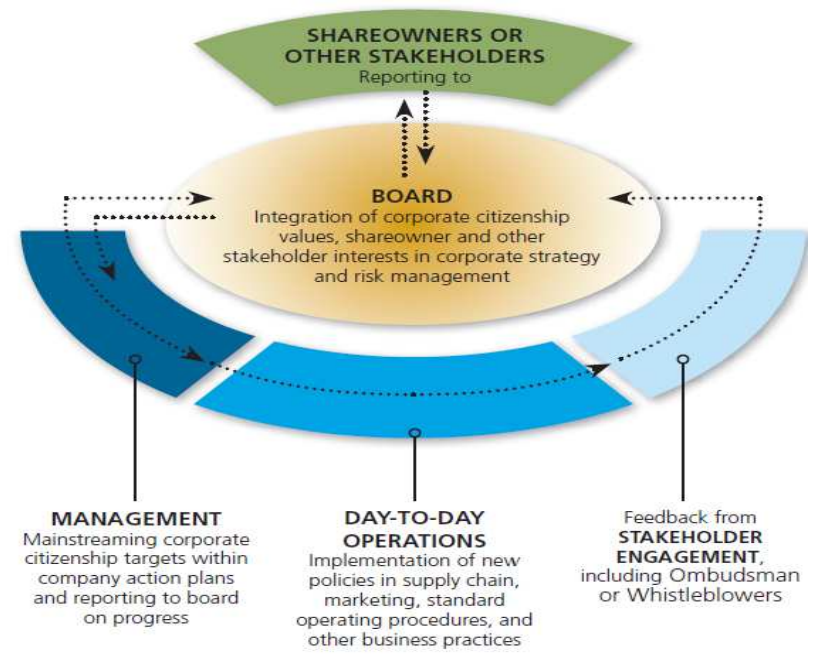

Figure 3: How Responsible Business Embedded into Function of BD

Source: IFC And Global Compact 2009 
Relative premium: Measuring the value of good governance in 3 regions

\begin{tabular}{r|r|r|r|r|r|} 
Average premium that investors are willing to pay for a well-governed company, by region, percent \\
Europe, United States
\end{tabular}

Figure 4: McKinsey Measures Value of CG.

Table 4: Summary on Obligations of MGT with Shareholders

\begin{tabular}{|l|c|}
\hline \multicolumn{1}{|c|}{ Items } & Note \\
\hline With enterprises & Act within their powers and for benefits of enterprises \\
\hline With their own & Carry out duties with skill and care \\
\hline With Firm assets & Not permit wastage of assets; \\
\hline With auditor & Furnish them with all information and explanations; \\
\hline
\end{tabular}

Source: CACG 1999 Code, King Committee and Director Institutes in South Africa 

